\title{
Stability of anti-HIV antibodies in serum samples stored for two to eighteen years periods
}

\author{
Estabilidade dos anticorpos anti-HIV em amostras de soro armazenadas \\ por períodos de dois a dezoito anos
}

Marcia Jorge Castejon ${ }^{1}$; Rosemeire Yamashiro²; Camila Cardoso de Oliveira33; Carmem Aparecida de Freitas Oliveira ${ }^{4}$; Mirthes Ueda ${ }^{5}$

\begin{abstract}
Introduction: The antibodies have an important role in the serodiagnosis, constituting the most widely used biomarkers to detect and confirm various diseases. Objective: To investigate the reproducibility of anti-human immunodeficiency virus (HIV) antibodies reactivity, to assess the stability of the sera samples stored at $-20^{\circ} \mathrm{C}$ for two to eighteen years. Method: Sera were collected in the period 1988-2004 for routine anti-HIV antibodies diagnostic testing. The remaining samples stored at $-20^{\circ} \mathrm{C}$, were analyzed in this study. Serum sample stability was assessed by enzyme-linked immunosorbent assay/enzyme immunoassay (ELISA/EIA), indirect immunofluorescence assay (IFA), and Western blot (WB) for detecting anti-HIV antibodies. The previously found results (1988-2004) and those obtained in 2006 were subjected to Kappa index analysis. Result: In the period 1988-to 2004, the degree of concordance of the ELISA/EIA, IFA and WB results were considered, good $(k=0.80)$, regular $(k=0.35)$, and good $(k=0.63)$, respectively. Conclusion: Regarding HIV serologic test, the serum samples were stable for 18 years in ELISA/EIA and for 4 years in IFA technique, however, for the WB methodology it was not possible to determine the time of stability of the anti-HIV antibodies.
\end{abstract}

Key words: serum; anti-HIV antibodies; storage; serum bank; time.

\section{INTRODUCTION}

Laboratory tests to diagnose infection with the human immunodeficiency virus (HIV) have been used for three decades and, up to now, they are still an important tool in the diagnosis and the quality of blood evaluation in haemotherapy units ${ }^{(7)}$. Therefore, the results of serological tests must be accurate and be correctly taken, because the medical and social importance of a positive HIV test ${ }^{(5)}$.

The enzyme immunoassay (ELISA/EIA) technique has been worldwide used as initial serological screening for detection of anti-HIV antibodies, and the samples with positive reactivity in these tests have been confirmed by Western blot (WB) and indirect immunofluorescence (IFI) techniques ${ }^{(14)}$.

The antibodies have an essential role in serodiagnosis and represent the most widespread biomarkers used for detection and confirmation of various diseases. Given its specific affinity for the antigen, the integrity of the three-dimensional chemical structure of these molecules is crucial for this interaction. Structural changes or molecular aggregation, depending on storage conditions, lead to a decrease in the antibodies activity, which may lead to false negative results ${ }^{(17)}$.

The degradation of stored biological material is an important factor to be investigated. When the samples are retested after stored for long time, this evaluation became complex. When results were not reproduced, it is difficult to verify if material degradation occurred in fact, or if the difference is results is due to the use of more sensitive laboratory tests developed over time ${ }^{(18)}$.

For many years, the excess of material of biological specimens collected to perform diagnostic procedures has been stored, in order to confirm a diagnosis later or for potential use in future research $^{(16)}$. In this context, the maintenance of serum sample stored frozen and held for future studies has been extremely

First submission on 21/10/13; last submission on 10/07/14; accepted for publication on 12/07/14; published on 20/08/14

1. MSc in Genetics and Evolution-Universidade Federal de São Carlos (UFSCar); scientific researcher III at Instituto Adolfo Lutz (IAL), São Paulo.

2. Bachelors degree in Biology-Universidade de Mogi das Cruzes (UMC); scientific researcher II at IAL, São Paulo.

3. MSc in Statistics-Universidade de São Paulo (USP); scientific researcher I at IAL, São Paulo.

4. MSc-Coordenadoria de Controle de Doenças da Secretaria de Estado da Saúde de São Paulo (CCD-SES/SP); scientific researcher VI at IAL, São Paulo.

5. Post-doctoral in Immunology-Universidade da Califórnia; scientific researcher VI at IAL, São Paulo. 
useful in assessing the transmission of various pathogens. Moreover, the availability of viable stored material enables making inquiries about health problems in the past, with the use of current and advanced technological resources. Some of the benefits resulting from the use of stored biological samples in research proved to be of great social relevance ${ }^{(11)}$.

The access to biological materials of biobanks associated with detailed clinical information are of inestimable value, not only for research purposes but also in field service, with obvious benefits to society ${ }^{(2)}$. Thus, a quality management plan, with the appropriate standard operating procedure, is essential in technical operations involving biospecimens ${ }^{(19)}$.

Stability studies on biomolecules stored for long periods under controlled conditions are rare and restricted to a limited number of proteins and analytes ${ }^{(8)}$. Due to scarcity of available data on which adverse effect the long-term storage may cause in the antibodies configuration, protein structures that are inclined to denaturation, it is particularly relevant to conduct a research through implementation of sensitive and specific assays. The concern with the storage time of the serum is related to various factors, such as temperature and samples freezing and thawing processes, which may cause occasional changes in the results of a particular test due to physical decay and, consequently, the biochemical modifications of antibodies of interest ${ }^{(3,4,9,10,15)}$.

\section{OBJECTIVE}

With the availability of serum samples with known reactivity regarding the anti-HIV antibodies and because the lack of an established norm in relation to the storage time of clinical and biological samples, this retrospective study was proposed to investigate the stability of sera stored for periods of two to eighteen years. The stability of specific antibodies was evaluated by the reproducibility of anti-HIV results, using sensitive and specific assays used in the routine of Laboratory of the Center of Immunology at Instituto Adolfo Lutz (IAL), São Paulo-SP, Brazil.

\section{METHOD}

The study was approved by the Human Research Ethics Committee-IAL (document nº 017/2011).

The sera used were from the remaining samples of routine diagnostic detection for anti-HIV antibodies, for the period
1988-2004, which were stored and frozen at $-20^{\circ} \mathrm{C}$ in the Laboratory of HIV/Aids of the Center of Immunology-IAL.

Aspects relating to confidentiality and privacy of clinical and laboratorial information and patients identification were considered essential, so we used the not linked anonymous study. Serological tests performed in serum samples, stored for this retrospective study, did not diverge from the scope in which they were intended, i.e., detection of anti-HIV antibodies.

In this retrospective study, serum samples stores during the period 1988-2004 were analyzed in 2006. The selection criteria to establish the number of serum samples $(n=1,000)$ was according to availability of laboratory reagents, which were intended for routine diagnosis. The selection of samples to perform the proposed evaluation was performed randomly, using the Microsoft Office Excel tools (Microsoft Corp., Redmont, WA, USA).

In 2006, to perform stability analysis of the sera by ELISA/EIA reproducibility of results were grouped by length of storage time, in order to ascertain the presence of adverse effects on serum over the years. Groups were set/established so that the number of samples in each block was higher than 100, as following described: 19881990 ( $n=227)$; 1991-1993 ( $n=101) ; 1994-1996(n=136)$; 1997-1999 $(n=116) ; 2000-2002(n=159)$; and 2003-2004 $(n=106)$, total 845 sera. Therefore, for the indicated periods, the storage time of these sera were 18-16 years, 15-13 years, 12-10 years, 9-7 years, 6-4 years, and 3-2 years, respectively.

In IFI assay, the classification of serum samples groups per time period was different from that established for ELISA/ EIA, according to the number of samples analyzed by the first methodology. Thus, to a more homogenous sample distribution in the evaluation of reproducibility of IFI tests results, the following periods were established: 1988-1992 $(n=106)$; 1993$1997(n=103)$; 1998-2002 $(n=79)$; 2003-2004 $(n=38)$.

According to the criteria established in this study, the number of serum samples analyzed in WB test was much lower than those in ELISA/EIA and IFI methodologies. Thus, to evaluate the reproducibility of the results, we adopted the recommendation of the International Organization for Standardization/Technical report (ISO/TR) 14468/2010 ${ }^{(13)}$, where sera were divided in groups of, at least, 20 samples per time period. Thus, two groups were formed: 1988-1997 and 1998-2004, with 26 sera in each.

Serum samples were initially subjected to ELISA/EIA (Vironostika HIV Uni-Form Plus 0 (Biomérieux SA, France) or Murex HIV 1.2.0 (Abbott Diagnostics, United Kingdom). Results were considered as reactive, non-reactive, and indeterminate, 
according to test reactivity threshold or cut-off, according to calculations determined by manufacturers of each set of diagnostic reagents used.

IFI tests (IFI-HIV-1 [BioManguinhos-Fundação Oswaldo Cruz \{FIOCRUZ\}], Brazil) and WB tests (HIV blot 2.2 [Genelabs Diagnostics], Singapore) were used as confirmatory, and results were expressed as positive, negative, and indeterminate, in compliance with the reactivity patterns recommended by manufacturers of the respective reagents.

The reactive or indeterminate results in ELISA/EIA were initially evaluated by IFI-HIV-technique, and whether indeterminate or negative results, they were analyzed by WB.

The diagnostic reagents sets underwent evaluation procedures through commercial seroconversion and performance panels (Boston Biomedica, Inc - Cambridge, MA, USA).

\section{Statistical analysis}

Results were analyzed in Microsoft Office Excel (Microsoft Corp., Redmont, WA, USA) and STATISTICA software (version 11 Tulsa, OK, USA).

The agreement between results of HIV tests performed in 19882004 and in 2006 was assessed using kappa statistics (Cohen, 1960) ${ }^{(6)}$, according to the period of time established for each technique used.

The interpretation of agreement levels, according to kappa values $(k)$, was performed based on the method proposed by Altman (1999) $)^{(1)}$, adapted to Landis and Koch (1977), which $k<0.20$ value represents poor reproducibility; $0.21-0.40$ regular; $0.41-0.60$ moderate; $0.61-0.80$ good; and 0.81-1.00 very good agreement.

\section{RESULTS}

From 1.000 randomly selected samples, 155 (15.5\%) sera could not be included in the study for the following reasons: sample was not found, insufficient volume of sample, or sample with gelatinous aspect. The 845 serum samples that could be evaluated showed, in its first analysis, the following results: 376 (44.5\%) HIV non-reactive, 431 (51\%) HIV reactive, and 38 (4.5\%) indeterminate samples.

In the evaluation performed in 2006, from 845 samples that were subjected to ELISA/EIA, 385 (45.6\%) showed non-reactive, $425(50.3 \%)$ reactive, and 35 (4.1\%) indeterminate results.

The 460 (54.4\%) sera with reactive (425) and indeterminate (35) results in ELISA/EIA were analyzed by IFI assay for confirmatory stage. However, only $326(70.9 \%)$ samples could be analyzed to assess the reproducibility once they presented previous results in this methodology. The remaining 134 (29.1\%) samples were not evaluated. In 326 sera analyzed in IFI, in 2006, the following results were found: 28 (8.6\%) negative, 225 (69\%) positive, and 73 (22.4\%) indeterminate.

Following the criteria described in this study methodology, sera with negative $(n=28)$ and indeterminate $(n=73)$ results in IFI assay would be analyzed in WB. However, from 101 sera, 49 (48.5\%) were not evaluated for reproducibility because they had not been previously analyzed by WB technique; the remaining 52 sera (51.5\%) showed the following results in this assay: two (3.8\%) negative, 20 (38.5\%) positive, and 30 (57.7\%) indeterminate.

Data concerning sample reproducibility in each methodology are shown in Table 1. It is observed that, according to the criteria established for interpretation of index $k$, the degree of agreement to ELISA/EIA - period 1988-2004 -, therefore referring to 18 years of storage at $-20^{\circ} \mathrm{C}$, was considered good, and about $90 \%$ of agreement was observed. If stricter evaluation criteria were used for this methodology, we consider only the periods when index $k$ value was equal or greater than 0.8 and, thus, ensuring the highest level of sera stability, the optimal storage time to detect anti-HIV antibodies was 12 years (i.e., after 1994), with about 93\% of agreement average observed.

The IFI assays results reproducibility, evaluated in the same period (1988-2004), was regular $(k=0.35)$, with agreement about $76 \%$, but kappa values were low, especially in periods before 2003. Through the technique features for visualizing the reaction, fungal contamination was detected in some sera analyzed. This, besides impairing test performance, indicates inadequate monitoring of these samples. So, results were more reproducible $(k=0.65)$ in samples collected after 2003, therefore, the stability was kept for four years

In the analysis of results of 52 serum samples, using WB methodology, during 1988-2004 period, the reproducibility was considered good $(k=0.63)$. However, when divided in two periods - 1988-1997 and 1998-2004 -, this index decreased significantly ( $k=0.52)$, and reproducibility was classified as moderate. Because of this, it was not possible to establish the exact time of storage in which serum samples showed good stability level.

Table 2, shows the number of samples with original results and those detected in 2006. The Figure shows these respective data in their percentage. It is also noticed that the instability of the sera was much more pronounced in IFI assay, when compared to the other methodologies used. 
TABLE 1 - Evaluation of reproducibility of the results of serum samples grouped in different time periods in ELISA/EIA, IFI and WB methodologies

\begin{tabular}{|c|c|c|c|c|c|c|c|c|}
\hline Period (year) & $\begin{array}{l}\text { Number of } \\
\text { samples }(n)\end{array}$ & $\begin{array}{c}\text { Kappa index } \\
(k)\end{array}$ & $95 \% k \mathrm{CI}$ & $p$ value & $\begin{array}{c}\text { Degree of } \\
\text { concordance }\end{array}$ & $\begin{array}{c}\text { Number of } \\
\text { concordant } \\
\text { results }\end{array}$ & $\begin{array}{c}p \text { observed } \\
\text { concordance } \\
(\%)\end{array}$ & $\begin{array}{c}95 \% \mathrm{CI} \\
\text { for observed } \\
\text { concordance }\end{array}$ \\
\hline \multicolumn{9}{|c|}{ ELISA/EIA } \\
\hline 1988-1990 & 227 & 0.71 & {$[0.59 ; 0.83]$} & 0.000 & Good & 194 & 85.46 & {$[80.19 ; 80.78$} \\
\hline 1991-1993 & 101 & 0.61 & {$[0.44 ; 0.78]$} & 0.000 & Good & 83 & 82.18 & {$[73.30 ; 89.08$} \\
\hline 1994-1996 & 136 & 0.87 & {$[0.72 ; 1.02]$} & 0.000 & Very good & 127 & 93.38 & {$[87.81 ; 96.93$} \\
\hline 1997-1999 & 116 & 0.94 & {$[0.78 ; 1.10]$} & 0.000 & Very good & 113 & 97.41 & {$[92.63 ; 99.46$} \\
\hline $2000-2002$ & 159 & 0.80 & {$[0.67 ; 0.93]$} & 0.000 & Good & 145 & 91.19 & {$[85.67 ; 95.10]$} \\
\hline 2003-2004 & 106 & 0.80 & {$[0.65 ; 0.95]$} & 0.000 & Good & 94 & 88.68 & {$[81.06 ; 94.01]$} \\
\hline 1988-2004 & 845 & 0.80 & {$[0.74 ; 0.86]$} & 0.000 & Good & 756 & 89.47 & {$[87.20 ; 91.46$} \\
\hline \multicolumn{9}{|c|}{ IFI } \\
\hline 1988-1992 & 106 & 0.10 & {$[0.02 ; 0.18]$} & 0.012 & Poor & 76 & 71.70 & {$[62.12 ; 80.02]$} \\
\hline 1993-1997 & 103 & 0.24 & {$[0.12 ; 0.36]$} & 0.000 & Regular & 77 & 74.76 & {$[65.24 ; 82.80]$} \\
\hline 1998-2002 & 79 & 0.53 & {$[0.37 ; 0.69]$} & 0.000 & Moderate & 62 & 78.48 & {$[67.80 ; 86.94$} \\
\hline 2003-2004 & 38 & 0.65 & {$[0.42 ; 0.88]$} & 0.000 & Good & 32 & 84.21 & {$[68.75 ; 93.98$} \\
\hline 1988-2004 & 326 & 0.35 & {$[0.27 ; 0.43]$} & 0.000 & Regular & 247 & 75.77 & {$[70.74 ; 80.32]$} \\
\hline \multicolumn{9}{|c|}{ WB } \\
\hline 1988-1997 & 26 & 0.52 & {$[0.18 ; 0.86]$} & 0.001 & Moderate & 20 & 76.92 & {$[56.35 ; 91.03$} \\
\hline 1998-2004 & 26 & 0.52 & {$[0.17 ; 0.87]$} & 0.002 & Moderate & 22 & 84.62 & {$[65.13 ; 95.64$} \\
\hline $1988-2004$ & 52 & 0.63 & {$[0.38 ; 0.88]$} & 0.000 & Good & 42 & 80.77 & {$[67.47 ; 90.37]$} \\
\hline
\end{tabular}

ELISA/EIA: enzyme-linked immunosorbent assay/enzyme immunoassay; IFI: indirect immunofluorescence; WB: Western blot; CI: Confidence Intervals.

TABLE 2 - Number of samples with reactive/positive, non-reactive/negative and indeterminate results previously detected and those obtained 2006. According to the methodology used

\begin{tabular}{cccccccc}
\hline \multirow{2}{*}{$\begin{array}{c}\text { Result } \\
\text { (categorical) }\end{array}$} & \multicolumn{6}{c}{ ELISA/EIA* } & \multicolumn{2}{c}{ IFI } & \multicolumn{3}{c}{ WB } \\
\cline { 2 - 8 } & Previous & 2006 & Previous & 2006 & Previous & 2006 \\
\hline $\begin{array}{c}\text { Non-reactive* } \\
\text { negative }\end{array}$ & 376 & 385 & 12 & 28 & 01 & 02 \\
\hline $\begin{array}{c}\text { Reactive*/ } \\
\text { positive }\end{array}$ & 431 & 425 & 286 & 225 & 23 & 20 \\
\hline Indeterminate & 38 & 35 & 28 & 73 & 28 & 30 \\
\hline Total & 845 & \multicolumn{3}{c}{326} & & 52 \\
\hline
\end{tabular}

ELISA/EIA*: reactive and non-reactive result.

ELISA/EIA: enzyme-linked immunosorbent assay/enzyme immunoassay; IFI: indirect immunofluorescence; WB: Western blot.

\section{DISCUSSION}

Conducting this work was of great importance, due to scarcity of data available in the literature, and numerous inquires received by researches and specialized technicians, working in the HIV/Aids area in several research and teaching institutions, regarding the reactivity and durability of serum antibodies produced against different pathogens, particularly HIV. Although this study did not performed measurement of immunoglobulins ${ }^{(15)}$ and avidity tests for analyzed samples,

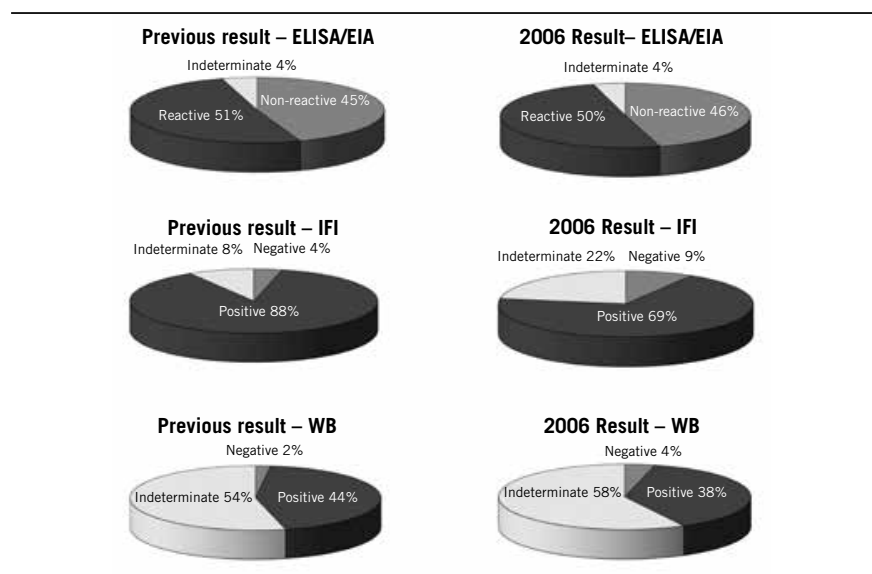

FIGURE - Percentage of reactive/positive, non-reactive/negative and indeterminate results previously detected and those obtained 2006 in ELISA/EIA, IFI, and WB methods for anti-HIV antibody

ELISA/EIA: enzyme-linked immunosorbent assay/enzyme immunoassay; IFI: indirect immunofluorescence; WB: Western blot; HIV: buman immunodeficiency virus.

index $k$ values detected showed that depending on the methodology used, the storage time of serum sample affects the anti-HIV antibodies detection.

In this study, it was observed that samples showed reproducible results for 18 years in ELISA/EIA methodology, and for four years in IFI technique. However, during analysis of results reproducibility in WB methodology, it was not feasible to determine the stability time of sera, due to index kappa value $(k=0.52)$ obtained in the two established periods. Even following the criteria recommended by ISO/TR $14468^{(13)}$, i.e., preparing groups of at least 20 samples for 
each time period, when sera were subdivided into two periods (19881997 and 1998-2004), the index kappa was only moderate. Perhaps, this change occurred because of the small number of samples in each period, and may not necessarily be a reflection of the reproducibility of these 52 samples in the period of 1988-2004, when there was a significant increase in index $k$ value. Thus, this evaluation was impaired by the inability to determine the exact period of stability for WB. It is necessary, in further studies, to evaluate a larger number of samples in order to establish a more accurate period of time.

In 61 serum samples (21.3\%), with previously positive results by IFI, it was found that positivity was not kept, when evaluated in 2006. Confirmatory tests are designed to achieve more specificity and loss of serum stability may produce false negative results, since sensitivity is generally lower than screening tests. Results reproducibility of laboratory assays is critical, whether in research or diagnostic laboratories. Given this, it is recommended that the researcher have knowledge about the influence of long-term storage of the antibody of interest in serum sample and the type of assay used.

Other cares are fully advisable, such as planning the biological sample storage in ideal conditions, allowing the use of the material in future investigations. Since the moment of the material collection, it is necessary to define necessary to define the sampling, transport, and storage procedures, as well as monitoring equipments to ensure sample integrity. Strict control of these conditions provides an added value to the samples, allowing to ensure quality, traceability, and reproducibility of results ${ }^{(16)}$. Although constant monitoring of storage equipments are part of quality control management at IAL, we detected fungal contamination in some serum analyzed in this investigation by IFI technique, which reveals evidence of irregular storage of these samples. Regarding to pre-analytical stage, the process control was not feasible due to the blood collection had been performed in different healthcare units.

More and more, there is a demand in actualize systems that ensure the quality of sera, such as the implementation of institutional biobanks. Quality control of stored biological materials is a prerequisite for the success of research studies, since it constitutes an important indicative parameter of sample degree of conservation and, thereby, ensuring the results reproducibility.

According to Gislefoss (2010) studies ${ }^{(12)}$, storage conditions may be crucial for the quality of the samples. When this happens, the robustness of analytical methods may change regarding sample variations and, therefore, component instability may invalidate the results of investigation. This data confirms that the knowledge on the stability of sera stored at $-20^{\circ} \mathrm{C}$ for long periods is essential to maintain the good quality of a serum bank, and to meet the demands of service provision requirements and to achieve reliable results in different laboratory tests, for research or assistance purposes.

In addition to concerns with the extension of storage process of biological materials, many researchers ${ }^{(4,9,15)}$ are interested in checking the effect of multiple consecutive cycles of freezing and thawing on antibody reactivity, since this procedure may cause occasional change in results of a particular test. In this study it was not possible to have evidence of the number of freezing and thawing cycles of analyzed samples, but the relevance of this aspect may be decreased, as found in Castejon et al. (2012) study ${ }^{(4)}$, which did not observed adverse effects on the reactivity of positive samples for detection of anti-HIV antibodies, without false-negative occurrence reaction, either false-positive results in negative samples for HIV, after multiple cycles of sera freezing and thawing.

In this context there are several parameters that must be taken into account to ensure the stability of the sera. Among them, as described by Souza (2012) ${ }^{(17)}$, there is evidence that the sample volume must not be lower than $10 \mu \mathrm{l}$ during serum storage once this may interfere with the results of reactions, since the evaporation process and antibodies adsorption on the surface of the storage vial modify sample concentrations. The IAL study was outlined to select samples with enough volume (minimum $150 \mu \mathrm{l})$ to perform the serological tests, therefore, samples with low volume were not part of the scope of this work.

The pre-analytical process, the mechanisms of sample degradation during storage, and the analytical methodologies used are factors directly associated with the quality of the serum samples. Thus, the combined knowledge on stability of component, the appropriate study design, and the choice of test methodology are essential for understanding the limitations which may occur, when using these samples for future studies.

According to the methodology of serological tests used, the storage time of serum sample interfered with the stability of detected anti-HIV antibodies. Kappa values show that serum samples stored for 18 years, when analyzed in ELISA/EIA methodologies, showed good reproducibility of the results, however, when evaluated in the IFI assay, a significant drop was observed in this index, and the reproducibility was classified as regular.

\section{CONCLUSION}

The present study showed that in relation to HIV tests, the serum samples were stable for 18 years in ELISA/EIA, and for four years with IFI technique. However, it was not possible to determine the time stability of the samples with WB methodology.

\section{ACKNOWLEDGEMENTS}

For André R. de Campos and Maria C. Sartorato, from Center of Immunology of IAL, for technical support in conducting this study. 


\section{RESUMO}

Introdução: Os anticorpos possuem papel fundamental no sorodiagnóstico e constituem os mais difundidos biomarcadores empregados na detecção e na confirmação de diversas doenças. Objetivo: Verificar a reprodutibilidade dos resultados de anticorpos contra o vírus da imunodeficiência bumana (HIV) para avaliar a estabilidade dos soros armazenados a $-20^{\circ} \mathrm{C}$ duranteperíodo de dois a dezoito anos. Método: Os soros utilizados foram provenientes de amostras remanescentes da rotina diagnóstica para detecção de anticorpos anti-HIV, no periodo de 1988 a 2004, os quais estavam armazenados em freezer $a-20^{\circ} \mathrm{C}$. A estabilidade das amostras de soro foi avaliada por meio de enzyme-linked immunosorbent assay/enzyme immunoassay (ELISA/EIA), imunofluorescência indireta (IFI) e Western blot (WB) para deteç̧ão de anticorpos anti-HIV, e os resultados dos testes realizados anteriormente (1988-2004)e os obtidos em 2006 foram submetidos à análise do indice Kappa. Resultado: No período de 1988-2004, os graus de concordância dos resultados do ELISA/EIA, IFI e WB foram considerados, respectivamente, bom $(\mathrm{k}=0,80)$, regular $(\mathrm{k}=0,35)$ e bom $(\mathrm{k}=0,63)$. Conclusão: No que diz respeito à sorologia para HIV, as amostras de soro foram estáveis por 18 anos no ELISA/EIA epor quatro anos na técnica de IFI, no entanto, para a metodologia de WB, não foi possivel determinar o tempo de estabilidade dos anticorpos anti-HIV.

Unitermos: soro; anticorpos anti-HIV; armazenamento; soroteca; tempo.

\section{REFERENCES}

1. ALTMAN, D.G. Practical statistics for medical research. Inter-rather Agreement. 8. ed. London: Chapman \& Hall, 1999. p. 403-9.

2. ASHTON-PROLLA, P. et al. Biobanco do Hospital de Porto Alegre: aspectos técnicos, éticos, jurídicos e sociais. Rev HCPA, v. 29, n.1, p. 74-9, 2009.

3. CAO, E. et al. Effect of freezing and thawing rates on denaturation of proteins in aqueous solutions. Biotechnol Bioeng, v. 83, n. 6, p. 684-90, 2003.

4. CASTEJON, M. J. et al. Avaliação dos múltiplos ciclos de congelamento e descongelamento na estabilidade dos soros para a detecção de anticorpos anti-HIV. Rev Inst Adolfo Lutz, v. 71, n. 3, p. 573-81, 2012.

5. CENTERS FOR DISEASE CONTROL. Current trends update: Serologic testing for antibody to human immunodeficiency virus. MMWR, v. 36, n. 52, p. $833-45,1988$.

6. COHEN, J. A. Coeficient of agreement for nominal scales. Educ Psychol Meas, v. 20, n. 1, p. 37-46, 1960.

7. CONSTANTINE, N. T.; ZINK, H. HIV testing technologies after two decades of evolution. Indian J Med Res, v. 121, n. 4, p. 519-38, 2005.

8. ELLIOTT, P.; PEAKMAN, T. C.; UK Biobank. The UK Biobank sample handling and storage protocol for the collection, processing and archiving of human blood and urine. Int J Epidemiol, v. 37, n. 2, p. 234-44. 2008.

9. FIPPS, D. R. et al. Efects of multiple freeze thaws and various temperatures on the reactivity of human immunodeficiency virus antibody using three detection assays. J Virol Methods, v. 20, n. 2, p. 127-32, 1988.

10. FRANKS, F. Protein stability: the value of 'old literature'. Biophys Chem, v. 96, n. 2-3, p. 117-27, 2002.
11. GAZE, R. et al. Reflexões éticas acerca dos estudos de soroprevalência de hepatites virais. Rev Assoc Med Bras, v. 52, n. 3, p. 162-9, 2006.

12. GISLEFOSS, R. E. Quality aspects of long-term stored samples studies in the janus serum bank of norway. Oslo, 2010. $40 \mathrm{f}$. Teses (Doctoral dissertation) - University of Oslo.

13. ISO. International Organization for Standardization -ISO/TR 14468 (E): selected illustrations of attribute agreement analysis. Geneva, Switzerland, 2010.

14. KIPTOO, M. K.; MPOKE, S. S.; NG'ANG'A, Z.W. New indirect immunofluorescence assay as a confirmatory test for human immunodeficiency virus type 1. East Afr Med J, v. 81, n. 5, p. 222-5, 2004.

15. PINSKY, N. A. Effect of multiple freezer-thaw cycles on detection of measles, mumps, and rubella virus antibodies. Clin Diagn Lab Immunol, v. 10, n. 1, p. 19-21, 2003.

16. SOMOZA, N.; TORÀ, M. Biological safety in the storage and transport of biological specimens from patients with respiratory diseases used in research settings. Arch Bronconeumol, v. 45, n. 4, p. 187-95, 2009.

17. SOUZA, A. P. A. et al. Influência de diferentes condições de armazenamento sob congelamento na reatividade de anticorpos séricos. $R B A C$, v. 44, n. 1, p. 39-43, 2012.

18. TWOROGER, S. S.; HANKINSON, S. E. Collection, processing, and storage of biological samples in epidemiologic studies: sex hormones, carotenoids, inflammatory markers, and proteomics as examples. Cancer Epidemiol Biomarkers Prev, v. 15, n. 9, p. 1578-81, 2006.

19. VAUGHT, J. B.; CABOUX, E.; HAINAUT, P. International efforts to develop biospecimen best practices. Cancer Epidemiol Biomarkers Prev, v. 19, n. 4, p. 912-5. 2010.

\section{MAILING ADDRESS}

Marcia Jorge Castejon

Instituto Adolfo Lutz; Av. Dr. Arnaldo, 351, $10^{\circ}$ andar; Cerqueira César; CEP: 01246-000; São Paulo-SP, Brasil; e-mail: mcastejon@ial.sp.gov.br. 